\title{
Exposure of natural Antarctic marine microbial assemblages to ambient UV radiation: effects on bacterioplankton
}

\author{
A. T. Davidson*, A. van der Heijden \\ Australian Antarctic Division, Channel Highway, Kingston, Tasmania 7050, Australia
}

\begin{abstract}
Seasonal ozone depletion over Antarctica leads to enhanced UVB (280 to $320 \mathrm{~nm}$ ) radiation throughout the period of greatest biological production. The effect of UV radiation on bacterioplankton has received little attention, and its effects on marine microheterotrophs and viruses, which mediate bacterial biomass, are poorly understood. This study examined the impact of ambient solar UV radiation on bacterioplankton in natural Antarctic microbial communities. Following a lag of $2 \mathrm{~d}$, bacterial concentrations increased all light treatments. Inhibition of bacterial growth increased with increasing UV irradiance and duration of exposure, reaching $27 \%$ inhibition in high UV treatments ( $\leq 2.0 \mathrm{~m}$ equivalent depth) compared to controls after $7 \mathrm{~d}$ exposure. Bacterioplankton growth rates declined in all treatments during post-UV incubation, particularly at lower UV irradiances $(\geq 3.0 \mathrm{~m}$ equivalent depth), indicating UV-induced inhibition of bacterial mortality during irradiation. Positive bacterial growth coincided with both phytoplankton mortality and increased microheterotroph concentrations following exposure to high UV irradiances. Exposure of Antarctic microbial communities to ambient UV is likely to increase microbial respiration of carbon in surface waters and reduce vertical carbon flux.
\end{abstract}

KEY WORDS: Bacteria $\cdot$ UV radiation - Antarctic Plankton

\section{INTRODUCTION}

UVB irradiance is enhanced throughout the period of greatest biological production in Antarctic waters. Stratospheric ozone concentration during spring commonly falls below $50 \%$ and may decline below $30 \%$ of pre-ozone-hole values (Weiler \& Penhale 1994). As a result, Antarctic UVB irradiances during spring are at least as high as at the summer solstice (Frederick \& Snell 1988). Ozone depletion persists until February (Jones \& Shanklin 1995), leading to a 50 to $100 \%$ increase in UVB around the summer solstice (Frederick \& Lubin 1994). Concern regarding the effect of UVB on the Antarctic biota has led to an extensive literature on the photobiology of Antarctic organisms. Most of this literature has focused on the impact of UVB on phytoplankton (e.g. Davidson 1998).

\footnotetext{
•E-mail: andrew.davidson@antdiv.gov.au
}

Any UVB-induced impacts on bacteria may have profound effects on carbon and energy flow at an ecosystem level. Bacteria are pivotal components of the marine microbial food web. They play a vital role in nutrient and element cycling and are the principal route of carbon flow in aquatic ecosystems. They contribute up to $40 \%$ of the planktonic carbon (Cho \& Azam 1990), process up to $80 \%$ of the primary production (Azam et al. 1983, Cho \& Azam 1990, Ducklow \& Carlson 1992), and have nutrient uptake potentials around 100 times faster than that of phytoplankton (Blackburn et al. 1998). Bacterioplankton also consume dissolved organic matter (DOM) to form bacterial biomass, thereby repackaging carbon and making it available to higher trophic levels (e.g. Pomeroy \& Weibe 1998).

Little information is available regarding the impact of UVB radiation on marine bacterioplankton but studies of the direct effects of UVB radiation on bacterioplankton show responses ranging from strongly in- 
hibitory to promoting bacterial growth. Reduced survival, production, ectoenzyme activity, DNA and protein synthesis of bacterioplankton and the absence photoinduced tolerance mechanisms have been reported (Herndl et al. 1993, Müller-Niklas et al. 1995, Aas et al. 1996, Jeffrey et al. 1996). However, the effect of UVB on bacterioplankton is mediated by the rate and depth of vertical mixing of the water column, rapid DNA repair mechanisms, enhanced recovery in nutrient replete conditions, and changes in bacterial community composition that favour UVB-tolerant species (Helbling et al. 1995, Müller-Niklas et al. 1995, Aas et al. 1996, Kaiser \& Herndl 1997). Herndl et al. (1993, 1997) and Kaiser \& Herndl (1997) proposed that bacterioplankton activity would be enhanced in waters exposed iv UVB. This enhañicemeñt was duc to rapid repair of UV damage exhibited by bacterioplankton, together with UVB-induced photodegradation of DOM to smaller molecules that are efficiently taken up by bacteria.

The role of UV-induced changes in the microbial community and their effect on bacterial mortality in Antarctic waters are unknown. UVB damages phytoplankton, bactivores and viruses (Suttle \& Chen 1992, Murray \& Jackson 1993, Sommaruga et al. 1996, 1999, Davidson 1998). Thus, indirect effects of UVB on nutritional status, grazing and mortality of bacterioplankton are likely. Here we examine the effect of ambient solar radiation on bacterioplankton concentration in natural microbial communities from Antarctic coastal waters.

\section{MATERIALS AND METHODS}

Studies were conducted at Davis Station $\left(68^{\circ} 35^{\prime} \mathrm{S}\right.$, $77^{\circ} 58^{\prime} E$ ), East Antarctica. Natural plankton assemblages were obtained at O'Gorman Rocks, approximately $2 \mathrm{~km}$ offshore on 7 January 1998. Seawater was pumped from $10 \mathrm{~m}$ depth into sterile carboys. The water was returned to the laboratory under subdued light and filtered through $200 \mu \mathrm{m}$ mesh into a sterile, acid-cleaned, polythene-lined $200 \mathrm{l}$ stainless steel drum (Fig. 1). Following gentle mixing, approximately $350 \mathrm{ml}$ aliquots of natural plankton assemblage were transferred to 132 sterile UV transmissive $500 \mathrm{ml}$ Nasco WhirlPak natural polythene bags.

Sample exposure. Exposure of the plankton in WhirlPak bags occurred in open-topped tanks through which natural seawater was pumped at approximately $3 \mathrm{~m}^{3} \mathrm{~h}^{-1}$. Seawater temperature in the tanks was $< \pm 1^{\circ} \mathrm{C}$ of ambient seawater and no significant difference was observed in temperature between the 2 incubation tanks $\left(< \pm 0.1^{\circ} \mathrm{C}\right)$. The plankton samples were held $30 \mathrm{~cm}$ beneath the water surface.

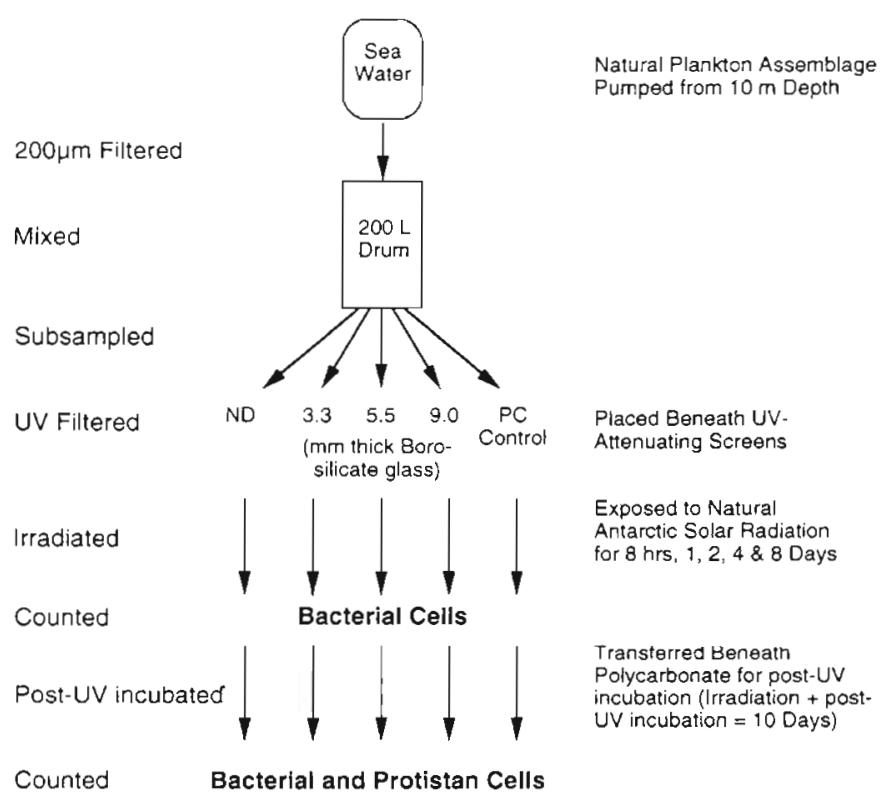

Fig. 1. Flow diagram of experimental protocol. ND = neutral density, $\mathrm{PC}=$ polycarbonate

Thirty bags were placed beneath either a polythene neutral density (ND) screen, or $3.3,5.5$ or $9.0 \mathrm{~mm}$ thickness borosilicate glass (Fig. 1, see Fig. 2 for screen transmittance). Equivalent water-column depths received by the plankton assemblages in each light treatment were calculated using Beer's Law (Kirk 1983) and the attenuation of surface irradiation by each screen (Table 1). A further 12 bags were held beneath polycarbonate sheeting, which removed UV wavelengths $<375 \mathrm{~nm}$. These comprised the control treatments and approximated a UV climate $\geq 20 \mathrm{~m}$ depth (Fig. 2, Table 1).

Sampling. At the end of each irradiance period 10 , $8 \mathrm{~h}, 1,2,4$ and 7 d), 3 replicate WhirlPak bags were thoroughly mixed and aliquots of $50 \pm 5 \mathrm{ml}$ from each bag poured into a sterile polycarbonate jar. The WhirlPak bags were then resealed and, together with a further 3 replicate bags from each light treatment, transferred to the control irradiance treatment and allowed to grow in the absence of short wavelength UV (postUV incubation). The total duration of UV irradiation plus post-UV incubation was $10 \mathrm{~d}$ for all bags. The 6 replicate WhirlPak bags for each light treatment and each irradiance time were randomly paired and the pairs pooled. Approximately $50 \pm 5 \mathrm{ml}$ was again transferred to sterile polycarbonate jars and transferred to the laboratory for microscopic determination of total bacterial concentration (as below). A known volume (approximately half) of the remaining sample was fixed with Lugol's iodine for determination of the concentration of protists (see below) (Fig. 1). 
Table 1 UV-attenuating screen, attenuation of surface erythemal UV, and equivalent water-column depth experienced by plankton in each experimental light treatment calculated using Beer's Law $\left(I / I_{0}=\mathrm{e}^{-k z}\right) . I_{0}$ and $I$ are the erythemal irradiance at the surface and $z$ meters depth respectively, and $k$ for erythemal UV was 0.4 (mean of 4 ice-edge sites of low seawater turbidity)

\begin{tabular}{|lcc|}
\hline Screen & $\begin{array}{c}\text { Attenuation } \\
\left(I / I_{0}\right)\end{array}$ & $\begin{array}{c}\text { Equivalent } \\
\text { depth }(\mathrm{m})\end{array}$ \\
\hline Neutral density & 0.632 & 1 \\
3.3 mm glass & 0.432 & 2 \\
5.5 mm glass & 0.310 & 3 \\
9.0 mm glass & 0.234 & 3.6 \\
Polycarbonate & 0 & 20 \\
\hline
\end{tabular}

Light measurement. Light measurements were made using an SR9910 Macam double grating spectroradiometer calibrated to the manufacturer's standardised deuterium and tungsten halogen light sources that are routinely calibrated by the National Physics Laboratory. Wavelengths between 280 and $400 \mathrm{~nm}$ were scanned at $1 \mathrm{~nm}$ steps every 5 min during the in vivo exposure of protist assemblages to solar radiation. Percent transmission of the UV-attenuating screens and WhirlPak bags was measured using a GBC 916 UV/VIS spectrophotometer (Fig. 2). Downwelling irradiance at each nanometer wavelength was

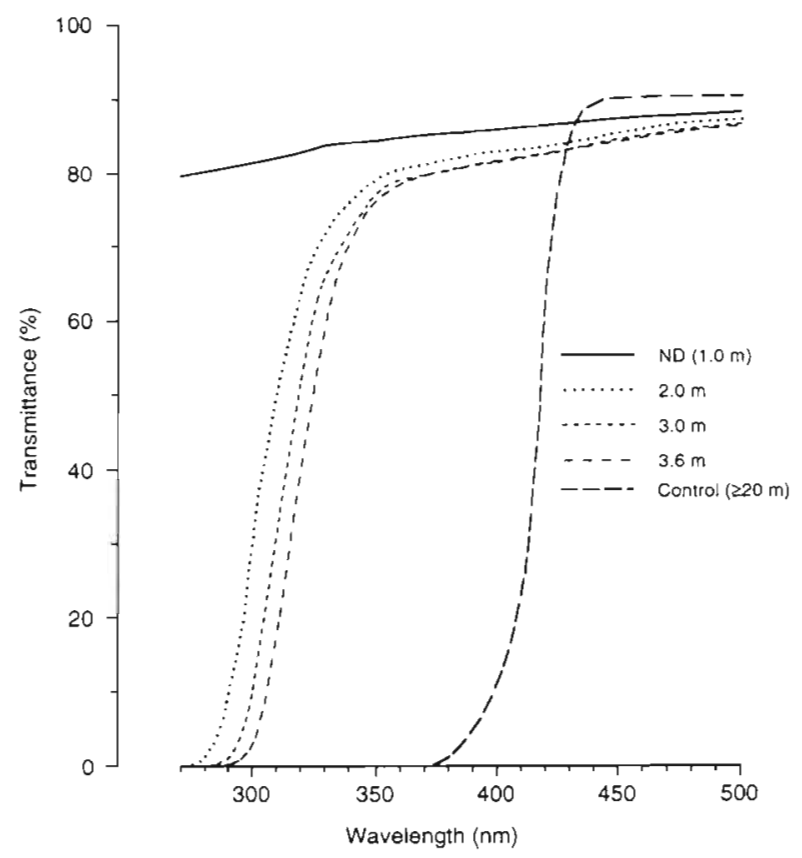

Fig. 2. Transmittance of UV beneath WhirlPak bags plus UVattenuating screens. ND = neutral density and Control $=$ polycarbonate screened treatment receiving no UV below $375 \mathrm{~nm}$ wavelength; $1.0,2.0,3.0,3.6$ and $\geq 20 \mathrm{~m}$ refer to the equivalent water-column depth of each light treatment then multiplied by the percent transmission of the WhirlPak bags and screens at each nanometer. The erythemal action spectrum was used to biologically weight the spectral data. Erythema was used due to its similarity to plant and DNA action spectra over wavelengths detected using the spectroradiometer, ease of cross-calibration with biometer data, and the fact that the experiments examined interactive responses of an entire plankton community for which more specific physiological weighting functions were not applicable. Cumulative erythemal dose was then calculated for each light treatment at each exposure time. Results were then integrated over $10 \mathrm{~min}$ intervals and a secondary intercomparison performed against coincident measurements of erythemal UV data collected using a 501B Solar Light UV-Biometer by the Australian Radiation Protection and Nuclear Safety Agency.

Bacterioplankton. Total bacterioplankton concentration was obtained from samples stained with 4'6 diamidino-2-phenolindole (DAPI) (Sigma). A known sample volume was filter-concentrated to approximately $2 \mathrm{ml}$ in a $25 \mathrm{~mm}$ diameter filtration apparatus fitted with $0.2 \mu \mathrm{m}$ pore size black polycarbonate membrane filters (Poretics). Sixty $\mu \mathrm{l}$ of $500 \mu \mathrm{g} \mathrm{ml} \mathrm{g}^{-1}$ solution of DAPI in Milli-Q water was added to the concentrates. The samples were mixed, held in the dark for 15 min, filtered to dryness, mounted on slides, and bacteria counted over 10 replicate fields using UV epifluorescence on a Zeiss Axiovert at $1000 \times$ magnification (Fig. 1).

Protists. Lugol's iodine-fixed samples (see 'Sampling') were sedimented, and observed using Nomarski optics on a Zeiss Axiovert inverted microscope at $400 \times$ or $1000 \times$ magnification. Cell counts were performed over 5 randomly chosen fields for each of the 3 replicate samples at each exposure time and light treatment (Fig. 1). Heterotrophic protists were identified under transmitted light by the absence of chlorophyll.

Statistical analyses. Analysis of variance (ANOVA) was performed using the total bacterial concentration during irradiation at the end of each irradiance period under each light treatment. Growth rates of bacterioplankton were calculated during UV incubation $(0-2$, 2-7 d exposure), and during post-UV incubation period (2 or 7-10 d incubation respectively) (Fig. 1). Growth rates were also analysed by ANOVA (independent variables of exposure duration, light treatment and post-UV incubation treatment).

Mean concentrations of autotrophs, heterotrophs and bacteria at each sample time and irradiance treatment were analysed by multiple linear regression. Statistical significance of the regressions were determined from the correlation coefficient. 


\section{RESULTS}

The erythemal downwelling solar irradiance varied greatly during the experiment. Diurnal fluctuations accounted for most of the variation but cloud contributed significantly to attenuation of erythemal irradiance during Days 3, 4, 6, and 7 of the experiment (Fig. 3A). Days 1,2 and 5 remained largely cloud-free. The increase in cumulative erythemal dose was approximately linear with increasing exposure time (Fig. 3B).

\section{Bacterioplankton}

Total bacterial concentration, measured at the end of each exposure period, showed an initial lày (Fiğ. 4). Concentrations then increased for the remainder of the exposure to solar radiation. Between 2 and $7 \mathrm{~d}$ irradiation the bacterial concentration increased approximately 5-fold, from around 0.2 to $1 \times 10^{6}$ cells $\mathrm{ml}^{-1}$. ANOVA showed a highly significant difference in bacte-
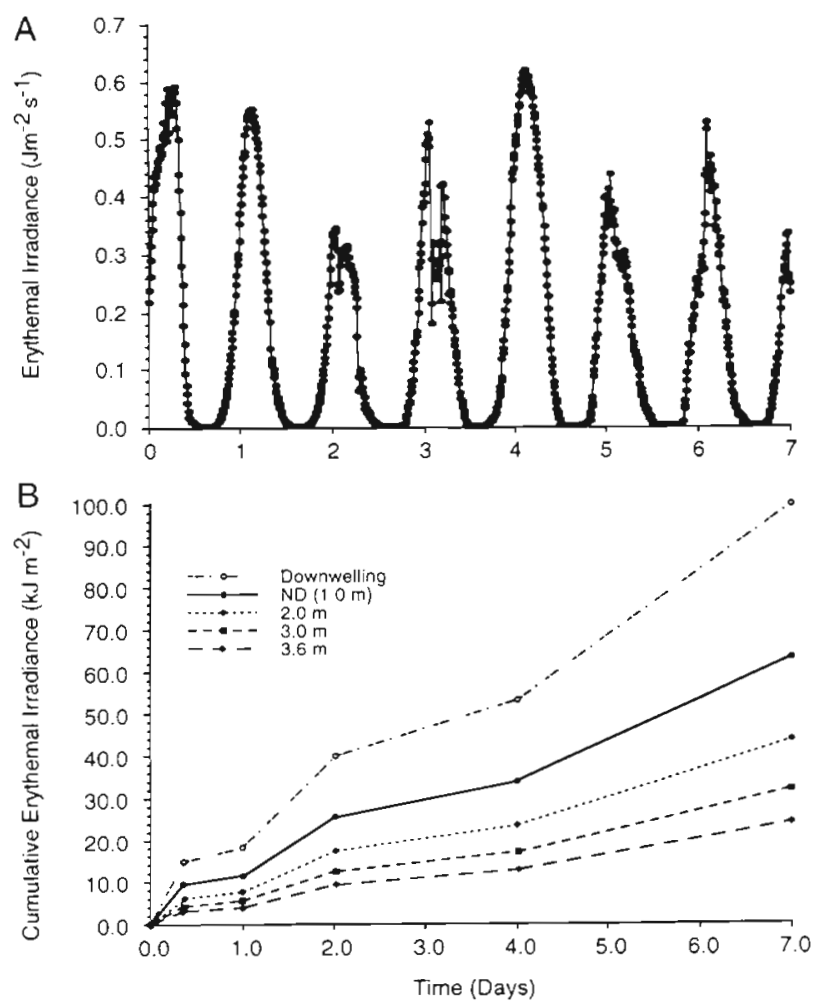

Fig. 3. Erythemal UV irradiance during exposure of natural plankton assemblages to ambient Antarctic solar radiation. (A) Downwelling and (B) cumulative downwelling erythemal irradiance received by plankton assemblages for each light treatment and exposure duration. Downwelling refers to the unattenuated downward erythemal UV flux; ND = neutral density; $1.0,2.0,3.0$, and $3.6 \mathrm{~m}$ refer to the equivalent watercolumn depth of each light treatment

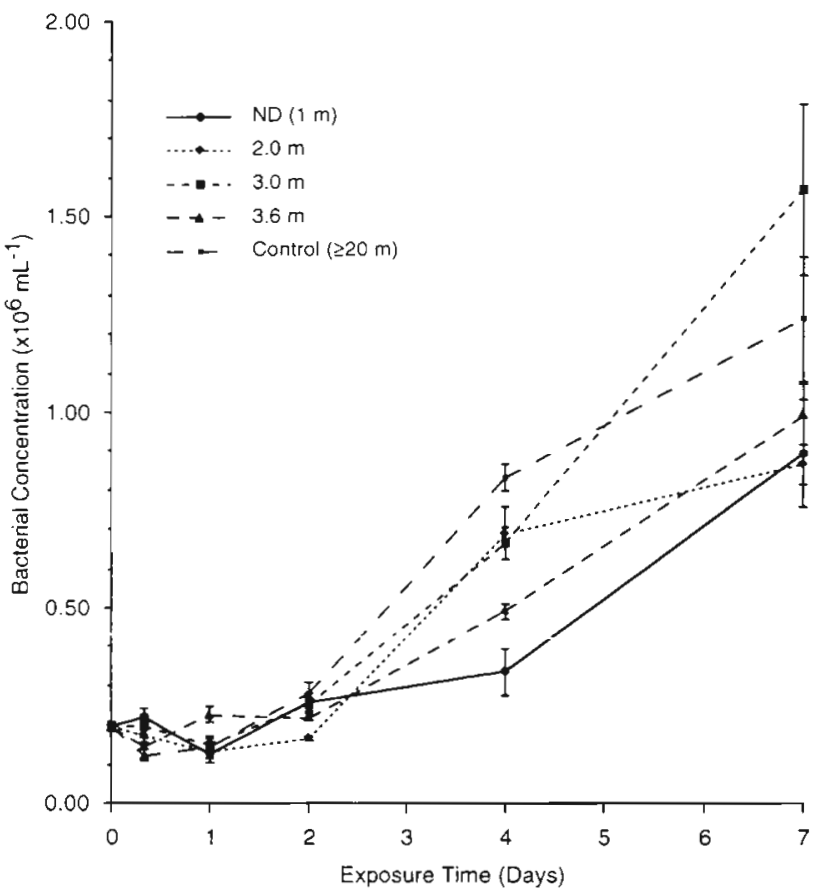

Fig. 4. Total bacterioplankton concentrations at the end of each irradiance period (no post-UV incubation). ND = neutral density and Control = polycarbonate screened treatment receiving no UV below $375 \mathrm{~nm}$ wavelength $\mathrm{h}_{i} .0,2.0,3.0,3.6$ and $\geq 20 \mathrm{~m}$ refer to the equivalent water-column depth of each UV-attenuated light treatment. Error bars indicate $\pm 1 \mathrm{SE}$

rial concentration with time $(F=66.11, \mathrm{p}=0.000, \mathrm{df}=1)$, reflecting extensive growth. Neither light treatment nor exposure duration alone caused significant changes in bacterial growth rate $(F=1.09, \mathrm{p}=0.36, \mathrm{df}=4$ and $F=0.27, \mathrm{p}=0.60, \mathrm{df}=1$, respectively) but the interaction of the two was highly significant $(F=6.43$, $\mathrm{p}=0.000, \mathrm{df}=4$ ). During $7 \mathrm{~d}$ exposure, plankton samples that were exposed at 1.0 and $2.0 \mathrm{~m}$ equivalent depth exhibited 26.1 and $27.5 \%$ inhibition of bacterial growth respectively in comparison with control treatments (Fig. 4). Lower light treatments exhibited slight inhibition or promotion of bacterial growth.

Bacterial concentrations and growth rates were measured after exposure for 2 or $7 \mathrm{~d} \pm$ post-UV incubation beneath UV-opaque polycarbonate (exposure + postUV incubation $=10$ d) (Fig. 5A). Bacterioplankton concentrations immediately after $2 \mathrm{~d}$ irradiation were lower than those incubated for $8 \mathrm{~d}$ in the absence of UV radiation, reflecting continued bacterial growth after irradiation. Growth rates during $2 \mathrm{~d}$ irradiation seldom differed from those during $8 \mathrm{~d}$ post-UV incubation. Bacterial growth rates in communities exposed to high light treatments $(\leq 2.0 \mathrm{~m})$ for $7 \mathrm{~d}$ were slower during irradiation but $\geq 0$ during the $3 \mathrm{~d}$ of post-UV incubation (Fig. 5A). Those exposed to lower UV irradiances for 

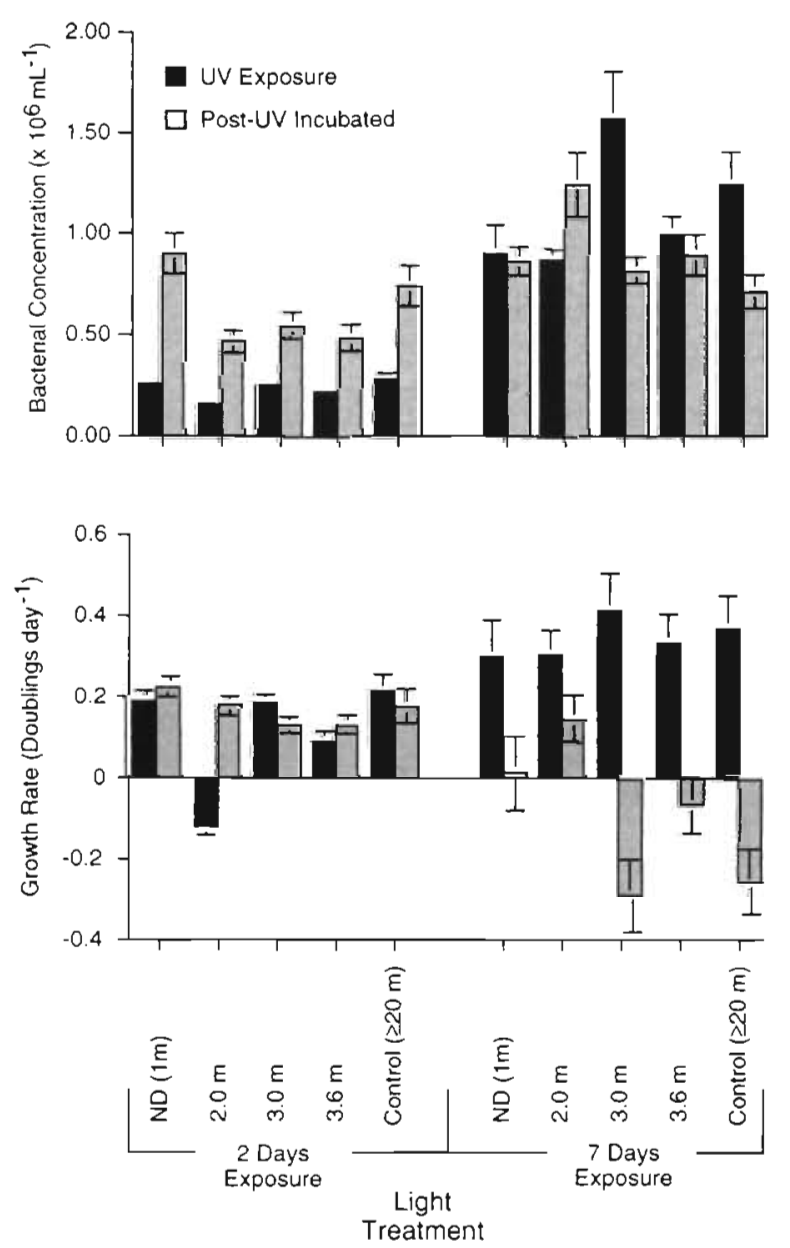

Fig. 5. (A) Concentrations and (B) growth rates of total bacterioplankton following 2 and $7 \mathrm{~d}$ UV exposure \pm post-UV incubation. $\mathrm{ND}=$ neutral density and Control = polycarbonate screened treatment receiving no UV below $375 \mathrm{~nm}$ wavelength; $1.0,2.0,3.0,3.6$ and $\geq 20 \mathrm{~m}$ refer to the equivalent water-column depth of each light treatment. Error bars indicate $\pm 1 \mathrm{SE}$

$7 \mathrm{~d}(\geq 3.0 \mathrm{~m}$ equivalent depth) exhibited more rapid growth during irradiation but had negative growth during post-UV incubation (Fig. 5B). ANOVA of showed changes in bacterioplankton growth rate were due to post-UV incubation and its interaction with exposure time $(F=110.57, \mathrm{p}=0.000, \mathrm{df}=1)$ and light treatment $(F=11.68, \mathrm{p}=0.000, \mathrm{df}=4)$.

\section{Protists}

Exposure of natural assemblages to near-surface UVB radiation changed the abundance and species composition of the auto- and heterotrophic protist assemblages (Davidson \& Belbin unpubl.). At low UV irradiances (3.0 and $3.6 \mathrm{~m}$ equivalent depth) total phytoplankton concentrations in post-UV incubated samples seldom differed from the control treatment (Fig. 6A). However, prolonged high irradiances $(1.0$ and $2.0 \mathrm{~m}$ equivalent depth for $\geq 2 \mathrm{~d}$ ) reduced phytoplankton to approximately $60 \%$ of their concentrations in the control treatment and significantly lower than their concentration at the beginning of the experiment (Time 0). UV-induced mortality of the dominant diatoms, namely Fragillariopsis curta (V.H.) Krieger and F. cylindrus (Grunow) Krieger, was principally responsible for the lower protist concentrations at high UV irradiances (Davidson \& Belbin unpubl.).

Prolonged exposure to high irradiances (1.0 and $2.0 \mathrm{~m}$ equivalent depth for $\geq 2$ d) increased microheterotroph concentrations (Fig. 6B). After $2 \mathrm{~d}$ exposure, their concentrations were around $50 \%$ higher than the control but decreased at longer exposure times. At 3.0 and $3.6 \mathrm{~m}$, equivalent depth concentrations decreased with increasing exposure time during the first $2 \mathrm{~d}$ of exposure, after which time they did not
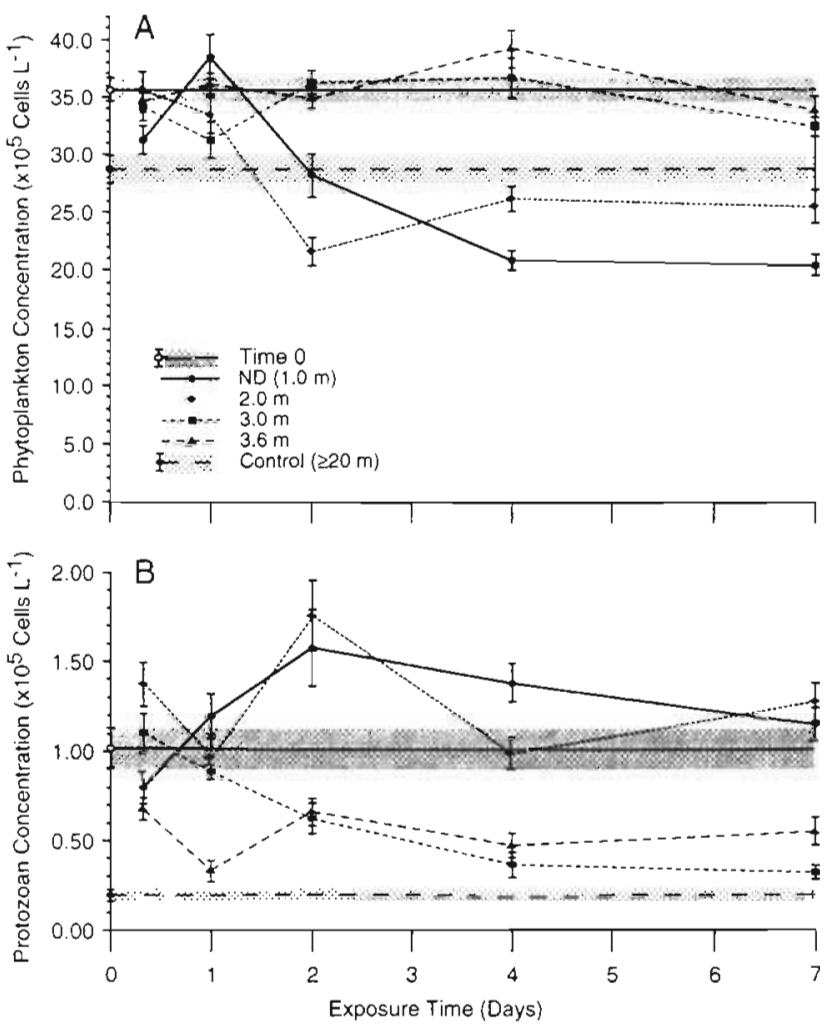

Fig. 6. Concentration of (A) autotrophs and (B) heterotrophs following $8 \mathrm{~h}, 1,2,4$ and $7 \mathrm{~d}$ irradiation + post-UV incubation (irradiation + post-UV incubation $=10 \mathrm{~d}$ ). ND = neutral density and Control = polycarbonate screened treatment receiving no UV below $375 \mathrm{~nm}$ wavelength; Time $0=$ the concentration of cells at the beginning of the experiment; 1.0, 2.0, 3.0, 3.6 and $\geq 20$ m refer to the equivalent water-column depth of each light treatment. Error bars indicate $\pm 1 \mathrm{SE}$ 
change significantly. Concentrations of microheterotrophs at low UV irradiances for $\geq 2 \mathrm{~d}$ were around 30 to $50 \%$ of that at high UV irradiances and were always significantly less than the control.

Concentration of autotrophic protists negatively correlated with microheterotroph concentration $(\mathrm{r}=0.628$, $0.05<\mathrm{p}<0.01, \mathrm{df}=18$ ). Bacterial concentration ( \pm post$U V$ incubation) did not significantly correlate with either the concentration of phytoplankton or protozoans.

\section{DISCUSSION}

\section{Bacterioplankton}

We ubserved a lag ơf $\leq 2$ d in bacterioplankton growth during irradiation. This lag has been attributed to inhibition of protein synthesis, primarily as a result of UVA wavelengths (Sieracki \& Sieburth 1986). Bacterioplankton growth after this lag showed significant inhibition (around $27 \%$ ) in high UV treatments $(\leq 2.0 \mathrm{~m}$ equivalent depth) and either slight inhibition or promotion of bacterioplankton growth in lower UV irradiance treatments. Helbling et al. (1995) reported greater UV-induced inhibition of Antarctic bacterioplankton. They showed that the viability of Antarctic bacterioplankton exposed to full solar radiation at $0.5 \mathrm{~m}$ depth for $12 \mathrm{~h}$ fell to $13 \%$ of unirradiated bacterioplankton, with around 17,67 and $16 \%$ of this mortality due to visible, UVA and UVB wavelengths respectively. Significant differences exist between our study and that of Helbling et al. (1995). The UV-induced loss of viability they reported may have been temporary and was repaired over the longer time scales of this study. In addition, Helbling et al. (1995) determined the bacterial viability immediately after irradiation while our study determined the total concentration of bacteria over longer exposures.

Bacteria show rapid recovery from UV-induced DNA damage by photoreactivation and excision repair (Herndl et al. 1993, Helbling et al. 1995, Müller-Niklas et al. 1995, Kaiser \& Herndl 1997). Our study included no artificial relief from UV exposure during irradiation. Instead, bacterioplankton experienced natural changes in solar radiation with the diurnal cycle and variations in cloud cover. We found that bacteria were able to repair UV-induced damage while residing in nearsurface waters.

We also found that bacterioplankton growth during irradiation differed significantly from that during postUV incubation. Post-UV-incubated bacterial growth declined following $7 \mathrm{~d}$ exposure, suggesting that secondary, community-level impacts of UV enhanced bacterial survival and growth during irradiation. These interactions are discussed below.
The susceptibility of bacterioplankton to UVB is mediated by their nutritional status. Nutrient-replete conditions reportedly cause faster UV-induced inhibition and recovery of bacteria than nutrient-depleted conditions, and the presence of primary producers may reduce the detrimental effects of UVB on bacterioplankton (Aas et al. 1996, Kaiser \& Herndl 1997, Sommaruga et al. 1997). Growth of bacterioplankton is strongly dependent on the concentration of DOM (Kähler et al. 1997) and is enhanced by senescence and mortality of protists (e.g. Blackburn et al. 1998, Kirchman 1999). Phytoplankton growth, production and survival are reduced by UV radiation (e.g. Davidson 1998). We found that phytoplankton concentration seldom differed significantly between irradiated and control light treatments at low UV irradiances. However: significant phytoplankton mortality was observed at the highest irradiances $(\leq 2.0 \mathrm{~m}$ equivalent depth). Lethal UVB doses have been reported to $10 \mathrm{~m}$ depth in Antarctic waters (Karentz 1989, Karentz \& Lutze 1990). $U V$-induced mortality of phytoplankton would, thus, be expected to enhance bacterioplankton growth and mediate the effect of UVB on bacteria at high UV irradiances. Furthermore, UVB radiation reportedly photodegrades DOM to smaller molecules that are more available to bacteria (Herndl et al. 1993, 1997, Lindel et al. 1995, Kaiser \& Herndl 1997). This dual action of UVB radiation is likely to promote bacterioplankton activity at high irradiances. However, other authors have found that UVB did not photodegrade refactory DOM or that photoalteration of bioavailable DOM inhibits bacterial growth (Thomas \& Lara 1995, Naganuma et al. 1996).

UVB can impair cellular activities and cause mortality of protozoans (e.g. Häder \& Häder 1991, Sommaruga et al. 1996). Sommaruga et al. (1999) showed that, in high altitude lakes, the concentration and grazing rates of bactivores was reduced by exposure to UVB wavelengths. However, protozoans differ greatly in the sensitivity to UV exposure (Giese 1953, Moller 1962). Our results showed that prolonged exposure of planktonic communities to high UV irradiances increased microheterotroph concentrations. Due to the uncertainty of determining the trophic status of protists and the size and palatability of the particles they graze, we have presented our data as total microheterotroph concentration. Protists were classified as heterotrophic on the basis of taxonomic identity and the absence of chlorophyll. Mixotrophic taxa may have been omitted from estimates of total microheterotroph concentration. Hall et al. (1993) showed that hetero- and mixotrophic protists can contribute equally to grazing of marine bacterioplankton populations. Known mixotrophic genera such as Chrysochromulina Lakey (see Estep \& MacIntyre 1989 and references therein) were 
a component of the protistan community in these experiments (Davidson unpubl.). Omissions of such mixotrophs may have resulted in underestimation of the concentration of bactivorous protists.

\section{Trophic interactions}

We observed a marked decline in growth during post-UV incubation, particularly in low UV treatments $(\geq 3.0 \mathrm{~m})$. We also found that exposure to high UV irradiances caused significant changes in key determinants of bacterioplankton activity, increasing the mortality of phytoplankton and the concentration of microheterotrophs. Previous studies of the effect of UVB on bacteria have examined their responses to isolation from other planktonic organisms and/or over short time scales (Herndl et al. 1993, Helbling et al. 1995, Müller-Niklas et al. 1995, Kaiser \& Herndl 1997) and are unlikely to incorporate the effects of such changes in the microbial community. Bothwell et al. (1994) showed that UV-induced changes in community structure and function can profoundly alter the effect of UV exposure on a single trophic level.

Bacterioplankton mortality is significantly determined by microheterotroph grazing, protozoans consuming around 3 to $12 \%$ of the bacterial biomass and 10 to $36 \%$ of their production daily (e.g. Kottmeier \& Sullivan 1990, Leakey et al. 1996). We found exposure of natural plankton assemblages to high UV treatments significantly increased the concentration of microheterotrophs and the increase was negatively correlated with the concentration of autotrophs. The increase in microheterotrophs was principally due to increased concentrations of ciliates, heterotrophic nanoflagellates and choanoflagellate spp. (Davidson \& Belbin unpubl.). These organisms consume bacteria and dissolved organic carbon (DOC) to support growth (e.g. Sherr \& Sherr 1994). High UVB irradiances may increase the availability of bacteria and DOC (see above). The absence of correlation between bacterial concentration and the concentrations of auto- and heterotrophic protists, the mortality of autotrophs or the UV irradiance that we observed in this study may reflect such top-down control. Low or negative bacterial growth rates during post-UV incubation may be due to reduced UV-induced inhibition of bactivores and/or photodegradation of DOC. Increased concentrations of both microheterotroph and bacteria in high UV treatments during post-UV incubation suggests increased bacterial production, probably as a result of phytoplankton mortality. Inactivation of viruses, changes in bacterial species composition and photoacclimation to high UV irradiances may also have contributed to the low UV-induced inhibition of bacterioplankton observed in this study (Arai et al. 1992, Suttle \& Chen 1992, Murray \& Jackson 1993, Fuhrman \& Noble 1995, Wilhelm et al. 1998, Sommaruga et al. 1999)

Our results show that prolonged exposure of natural planktonic communities to high UV irradiances increased the concentration of components of the microbial loop. Further research is required to determine the magnitude and mechanism by which microbial activity is enhanced but these changes in trophodynamics appear to be primarily elicited by UV-induced mortality of phytoplankton. Thus, increased UVB irradiance over Antarctica as a result of ozone depletion is likely to increase the amount of fixed carbon that is respired by the microbial community in surface waters and decrease vertical flux of carbon to deep water.

Acknowledgements. We gratefully acknowledge Colin Roy and Peter Geis from the Australian Radiation Protection and Nuclear Safety Agency for kindly providing UV-biometer data. We also wish to thank Kelvin Michael for advice regarding UV measurements, Simon Wright for his advice on programming, and S. Wright and $\mathrm{H}$. Marchant for their constructive criticism of this manuscript.

\section{LITERATURE CITED}

Aas P, Lyons MM, Pledger R, Mitchell DL, Jeffrey WH (1996) Inhibition of bacterial activities by solar radiation in nearshore waters and the Gulf of Mexico. Aquat Microb Ecol 11:229-238

Arai $T$, Nishijima $M$, Adachi $K$, Sano $H$ (1992) Isolation and structure of a UV-absorbing substance from the marine bacterium Micrococcus sp. AK.344. MBI Reports 1992, Marine Biotechnology Institute, Tokyo, p 88-94

Azam F, Fenchel T, Field JG, Gray JS, Meyer-Reil LA, Thingstad F (1983) The ecological role of water-column microbes in the sea. Mar Ecol Prog Ser 10:257-263

Blackburn N, Fenchel T, Mitchel J (1998) Microscale nutrient patches in planktonic habitats shown by chemotactic bacteria. Science 282:2254-2256

Bothwell ML, Sherbot D, Pollock CM (1994) Ecosystem response to solar ultraviolet-B radiation: influence of trophic level interactions. Science 265:97-100

Cho BC, Azam F (1990) Biogeochemical significance of bacterial biomass in the ocean's euphotic zone. Mar Ecol Prog Ser 63:253-259

Davidson AT (1998) The impact of UVB radiation on marine plankton. Mutat Res 422:119-129

Ducklow HW, Carlson CA (1992) Oceanic bacterial production. In: Marshall KC (ed) Advances in microbial ecology. Plenum Press, New York, p 113-181

Estep KW, Maclntyre F (1989) Taxonomy, life cycle, distribution and dasmotrophy of Chrysocromulina: a theory accounting for scales haptonema, muciferous bodies and toxicity. Mar Ecol Prog Ser 57:11-21

Frederick JE, Lubin D (1994) Solar ultraviolet radiation at Palmer Station, Antarctica. In: Weiler CS, Penhale PA (eds) Ultraviolet radiation in Antarctica. Measurements and biological effects. Antarctic Research Series, Vol 62, American Geophysical Union, Washington, DC, p 43-52

Frederick JE, Snell HE (1988) Ultraviolet radiation levels during Antarctic spring. Science 241:438-440 
Fuhrman JA, Noble RT (1995) Viruses and protists cause similar bacterial mortality in coastal seawater. Limnol Oceanogr 40:1236-1242

Giese AC (1953) Some properties of a photodynamic pigment from Blepharisma. J Gen Physiol 37:259-269

Häder DP, Häder MA (1991) Effects of solar radiation on Stentor coeruleus. Photochem Photobiol 54:423-428

Hall JA, Barrett DP, James MR (1993) The importance of phytoflagellate, heterotrophic flagellate and ciliate grazing on bacteria and picophytoplankton sized prey in a coastal marine environment. J Plankton Res 15:1075-1085

Helbling EW, Marguet ER, Villafañe VE, Holm-Hansen $O$ (1995) Bacterioplankton viability in Antarctic waters as affected by solar ultraviolet radiation. Mar Ecol Prog Ser 126:293-298

Herndl GJ, Müller-Niklas G, Frick J (1993) Major role of ultraviolet-B in controlling bacterioplankton in the surface layer of the ocean. Nature 361:717-719

Herndl GJ, Brugger $\Delta$, Hager S, Kaiser E, Obernosterer I, Reitner B, Slezak D (1997) Role of ultraviolet-B radiation on bacterioplankton and the availability of dissolved organic matter. Plant Ecol 128:42-51

Jeffrey WH, Pledger RJ, Aas $P$, Hager $S$, Coffin RB, Von Haven R, Mitchell DL (1996) Diel and depth profiles of DNA photodamage in bacterioplankton exposed to ambient solar ultraviolet radiation. Mar Ecol Prog Ser 137 : $283-291$

Jones AE, Shanklin JD (1995) Continued decline of ozone over Halley, Antarctica, since 1985. Nature 376:409-411

Kähler P, Bjørnsen PK, Lochte K, Anita A (1997) Dissolved organic matter and its utilization by bacteria during spring in the Southern Ocean. Deep-Sea Res 44:341-353

Kaiser E, Herndl GJ (1997) Rapid recovery of marine bacterioplankton activity after inhibition by UV radiation in coastal waters. Appl Environ Microbiol 63:4026-4031

Karentz D (1989) Report on studies related to the ecological implications of ozone depletion on the Antarctic environment. Antarct J US 23:114-115

Karentz D, Lutze LH (1990) Evaluation of biologically harmful ultraviolet radiation in Antarctica with a biological dosimeter design. Limnol Oceanogr 35:549-561

Kirchman DL (1999) Phytoplankton death in the sea. Nature 398:293-294

Kirk JTO (1983) Light and photosynthesis in aquatic ecosystems. Cambridge University Press, Cambridge

Kottmeier ST, Sullivan CW (1990) Bacterial biomass and production in pack ice of Antarctic marginal ice edge zones. Deep-Sea Res 37:1311-1330

Leakey RJG, Archer SD, Grey J (1996) Microbial dynamics in coastal waters of East Antarctica: bacterial production and

Editorial responsibility: Tom Fenchel,

Helsingør, Denmark nanoflagellate bactivory. Mar Ecol Prog Ser 142:3-17

Lindel MJ, Granéli W, Tranvik LJ (1995) Enhanced bacterial growth in response to photochemical transformation of dissolved organic matter. Limnol Oceanogr 40:195-199

Maller KM (1962) On the nature of stentorin. Compt Rend Lab Carlsberg 32:471-498

Müller-Niklas G. Heissenberger A, Puskaric S, Herndl GJ (1995) Ultraviolet-B radiation and bacterial metabolism in coastal waters. Aquat Microb Ecol 9:111-116

Murray AG, Jackson GA (1993) Viral dynamics: a model of the interaction of ultraviolet light and mixing processes on virus survival in seawater. Mar Ecol Prog Ser 102:105-114

Naganuma T, Konishi S, Inoue T, Nakane T, Sukizaki S (1996) Photodegradation or photoalteration? Microbial assay of the effect of UV-B on dissolved organic matter. Mar Ecol Prog Ser 135:309-310

Pomeroy LR, Weibe WJ (1998) Energetics of microbial food webs. Hydrobiologia 159:7-18

Sherr FR, Sherr BF (1994) Bactivnry and herhivory key roles of phagotrophic protists in pelagic food webs. Microb Ecol 28:223-235

Sieracki ME, Sieburth JMcN (1986) Sunlight-induced growth delay of planktonic marine bacteria in filtered seawater. Mar Ecol Prog Ser 33:19-27

Sommaruga R, Oberleiter A, Psenner R (1996) Effect of UV radiation on bactivory of a heterotrophic nanoflagellate. Appl Environ Microbiol 62:4395-4400

Sommaruga R, Obernosterer I, Herndl G, Psenner R (1997) Inhibitory effect of solar radiation on thymidine and leucine incorporation by freshwater and marine bacteria. Appl Environ Microbiol 63:4178-4184

Sommaruga $R$, Sattler $B$, Oberleiter $A$, Wille $A$, WögrathSommaruga S, Psenner R, Felip M, Camarero L, Pina S, Gironés R, Catalán J (1999) An in situ enclosure experiment to test the solar UVB impact on plankton in a high altitude mountain lake. II. Effects on the microbial food web. J Plankton Res 21:859-876

Suttle CA, Chen F (1992) Mechanisms and rates of decay of marine viruses in seawater. Appl Environ Microbiol 58 : $3721-3729$

Thomas DN, Lara RJ (1995) Photodegradation of algal dissolved organic carbon. Mar Ecol Prog Ser 116:309-310

Weiler CS, Penhale PA (1994) Preface. In: Weiler CS, Penhale PA (eds) Ultraviolet radiation in Antarctica. Measurements and biological effects. Antarctic Research Series, Vol 62, American Geophysical Union, Washington, DC, p xi-xii

Wilhelm SW, Weinbauer MG, Suttle CA, Jeffrey WH (1998) The role of sunlight in the removal and repair of viruses in the sea. Limnol Oceanogr 43:586-592

Submitted: May 31, 1999; Accepted: January 24, 2000

Proofs received from author(s): May 8,2000 